\title{
2 An Overview of the Apology
}

The contents of the five parts of Gerasimus's are basically: 1) means by which true religion can be discerned, 2) signs of a true disciple of the true religion, 3) a comparison between Christianity and other religions, 4) various testimonies to the life and work of Jesus Christ, and 5) answers to objections regarding the above arguments.

As with most Arabic apologetical treatises, Gerasimus's main purpose is twofold. First, it is intended to provide Christians with a handbook of ready response to questions posed by Muslims about Christianity. Secondly, it is to encourage wavering Christians in the face of Muslim missionary efforts. Gerasimus defends the credibility of Christian claims concerning the trinity, the incarnation, Christian law, and certain Christian practices where Muslim arguments had begun to sow doubt within the Christian community. ${ }^{17}$ Gerasimus endeavors to prove to his readers that Christianity can be attested to as the true religion, not only through scriptural demonstrations but also through rational thinking.

\subsection{The True Religion}

To explain the concept of religion, Gerasimus argues that there are two categories of religions: true and false. The only true religion is revealed by God, and the many false religions are from the devil. The true religion is concealed among the many false ones, and the only way to discover it is through "research and analogy, right discernment, and the refinement of senses" (Part 1). ${ }^{18}$

In trying to find a common ground with his opponents, Gerasimus lists three elements that true religion must possess: God, law and compensation. On the basis of these shared premises he then challenges his readers to decide, "through analogical deduction, clearness of statement, and the authenticity of evidences," which faith to adapt, defend, and adhere to. After laying out these three essential elements of religion, Gerasimus explains how one should go about discerning their authenticity in a religion (Part 1$)$.

17 Griffith 1979, 63-64.

18 The text of parts 1-4 of Gerasimus's Apology has yet to be definitively divided into verses and translated into English, thus at present it is not possible to provide more exact references for quotes from this text. These quotes are of the author's own translation. 


\subsubsection{Discerning the True Religion Through a Worshiped God}

Gerasimus starts by presenting the means by which the existence of God can be discerned. He reasons that human nature cannot fully contain the knowledge of God, thus, in order to discern the true god one must begin by examining the creation (human beings and nature) the reason behind it because God's imprints are in his creation (heaven and earth) and also because man is a reflection of God's image and likeness. . Gerasimus also uses analogical deduction. Like other Arab theologians, he endeavors to affirm that the existence of God can be inferred through logical deduction. In this he follows the same pattern of argument as Abū Qurrah in his treatise on the existence of God and true religion. ${ }^{19}$

Gerasimus compares "the mind of the Creator" to "the most noble and marvelous of the celestial beings, that is the sun, and to the most noble and marvelous creature on earth, that is man." In the analogy of the Creator and man, Gerasimus's search is directed by the fundamental conviction that human attributes mirror divine attributes: "we see in man, as long as he is preserved in the Image, many virtues that are from his Creator, who created him in His likeness and Image" (Part 1). These noble and excellent human attributes have their counterparts in God, reflecting God's own attributes, thus being indicative of what God is like, though they can never show us God's complete essence.

He concludes his discussion of these two analogies (the sun and man - which will be examined in more detail here in chapter 3) with the assertions that, A. the human mind cannot perceive these truths, and yet B. through analogies it is still possible to deduce a Trinitarian God. He supports this argument by summarizing an analogy used by Abū Qurrah: "If we pass by a vineyard, and we see it drilled, fenced, and planted, we realize that a man did this. But we don't know if this was one man or three men, because it could be either" (Part 1). ${ }^{20}$ With his analysis of the sun and of humanity, however, Gerasimus attempts to demonstrate a plurality within the divine, with God the Father acting as the first cause, and his word (the Son) and his Spirit manifesting his effects on creation.

Gerasimus returns to this point in Part 3 of the Apology where he compares Christianity with other religions. Based on the three foundations of all religions already mentioned, he affirms that the Christian Trinitarian God is the creator of heaven and earth, as Paul taught: "He gives to all life and breath, and all things" (Acts 17:25). Gerasimus then quotes Matthew 28:19 and John 1:1-4 as evidence of the Trinity. He then compares the Christian God with the gods of other religions, and states that none of these religions is able to teach what the Lord of all revealed in His Gospel.

19 Cf. Dick 1982.

20 Ibid. 197-198. 


\subsubsection{Discerning the True Religion Through a Law That Includes Lawfulness and Unlawfulness}

Gerasimus presents three kinds of law, earthly, Divine, and Satanic, which he adapts these from the well known apology of al-Kindī. ${ }^{21}$ The purpose of earthly law is to bring about justice and equity on earth. Humans are to return "like with its likeness." This means, for example, to return love with love or hatred with hatred. Divine law is from Heaven. It goes beyond returning like with its likeness. The Divine Law commands us to love our enemies and pray for those who persecute us. Through divine law, humanity can rise above human nature, and be elevated from earth to heaven; it transforms humans from earthly beings to gods. Through it we achieve divine perfection, which means returning good for evil, loving the persons who hate us, and treating with kindness those who mistreat us. Satanic law comes from the lower parts, under the earth. Its concerns are iniquity, injustice, and transgression. It pulls us down us from the middle level, to the level beneath the earth. We become devilish, returning love with hatred. Gerasimus concludes by inviting his reader to use this reality to discern the true religion by examining its law and responsibilities. Without doubt true religion applies the Divine law (Part 1).

In Part 3 Gerasimus returns to the subject of law, but this time to show that Christian law, that is love, is the spiritual law: "it is light and guidance, it raises us up from earth to heaven, from slavery to filiations, from defect to perfection." Gerasimus based his comments on Matthew 7:12 and Luke 6:31, "Therefore whatever you want men to do to you, do also to them," and John 13:34, "A new commandment I give to you, that you also love one another; as I have loved you."

Gerasimus then presents four kinds of love: natural love, carnal love, worldly/ human love, and spiritual love. Natural love is the love of parents for their children, but this is not a true genuine love since humans and animals both display it. Carnal love is the desire of the body, the love of a man for a woman. This is not true love either, and is not permanent, because when the beauty of a woman fades, carnal pleasure also ceases. The causes of worldly or human love are many and diverse: praise that the lover gives to his beloved, a gift received from a lover, etc. This love is not lasting and true either; if the cause ceases the love also ceases. Spiritual love is the true love that our Lord initiated and commanded us to practice. Our Lord taught us, "Greater love has no one than this, than to lay down one's life for his friends" (John 15:13). Gerasimus offers more scripture on love, rephrasing John 3:16 and quoting Luke 6:32-35 and Matthew 5:20, 39-41, 44-45, 48. He concludes that "this is the Divine Law and these are its commandments and its lawfulness and unlawfulness. These are the very same laws of Christians. No other religion is like it” (Part 3).

21 Cf. Bottini 1998; al-Hูūrī 2004, 126-127. 
Gerasimus continues in Part 3 by characterizing the laws of other religions. They command their followers to take advantage of each other, and they advocate vengeance and retaliation. These laws transform the natural man who is created in God's image into the image of a devouring beast. They return an insult for a simple word. They retaliate against an insult with beating and a beating with killing.

\subsubsection{Discerning the True Religion Through Eternal Reward or Punishment}

Gerasimus starts this section by defining the purpose of compensation in religion. It is our final reward; it can be either eternal bliss, or eternal punishment (Part 1). Then he moves on to define the two kinds of good: the true one and that which is assumed to be true. Our duty is to discern the true good. In order to assist in that, Gerasimus offers four characteristics of the true good. Of course, the characteristics of true evil are the opposite. First, true good must be beneficial in and of itself. Its benefits must not come by persuasion or monetary payment. Second, its benefits must be available to everyone. It would be contrary to its nature if it was good for some and not good for others. It is not like medicine [which is beneficial for ill people but of no use to healthy people]. Third, it must be valuable at all times, unlike satiating hunger with food. Fourth, it must be eternal, not temporal like happiness, blessings, and the glory of this world (Part 1). Gerasimus concludes his invitation to discern true good from evil: if any "good" lacks any of those four characteristics, it is not genuine but counterfeit.

In Part 3 Gerasimus confirms the verity of the Christian promise of reward and punishment, in that it demonstrates the four characteristics of genuine good. This good is union with God and the pleasure of His eternal bliss. Through grace, we become gods like Him, and have all that He has. This echoes Gregory of Nazianzus who wrote in his poem, De Incarnatione, "and since, then, God is made man, so man is perfected as God, and that is my glory."22 Gerasimus affirms his discussion of "good" with quotations from John 14:15-17, John 17:11, 20-24, and John 11:25-26.

After defining Christian good and the reward that awaits the believer, Gerasimus asks two questions: What is death? and What is life? He answers that man has two lives and two deaths. The bodily life is the unity of body and a soul. The spiritual life is the unity of the spirit with God, its creator. Bodily death is the separation of the spirit from the body; spiritual death is the isolation of the spirit from God, its creator. As the body takes life from the spirit, likewise the spirit gets its life from God.

Gerasimus continues to compare the spiritual life with the bodily life. He begins by describing how the Creator created human beings with an innate bodily attachment, that is, humans were created to love their bodies. God also created hunger in humans and provided sustenance that could satisfy human desire. Humans instinctively seek

22 Behr 2004, 275. 
and desire such nourishment, and when they find it, they are pleased. Without it, they are distressed. God also created a spiritual life in humans that shares features with the bodily life. The spiritual life contains an innate desire which is to love life in the spirit and its union with the Divine. It is natural for the healthy spirit to yearn for God. As the Psalmist wrote, "As the deer pants for the water brooks, so pants my soul for You, O God" (Psalm 42:1). However, if the spirit becomes corrupted, it will find pleasure in that which distresses and spoils it. Gerasimus gives the example of an eye. If the eye is healthy it desires light, but if it becomes diseased, it prefers what would ordinarily distress it, that is darkness. As God created sustenance for the body, He Himself became the sustenance for the spirit. He gave His life for us that we could be united with Him and enjoy His Divine eternity. ${ }^{23}$

Gerasimus concludes this part of the argument by stating that eternity with God is the reward that our Lord promised in His Gospel. We will enjoy this reward if we believe and practice His commandments, but if not, we will suffer separation from God. In contrast with this he presents a brief description of the rewards of other religions. These rewards are given out according to the laws of the deity that is worshiped, and depend on what traps Satan has laid out regarding the pleasures of this world, including eating and drinking.

\subsubsection{Additional Characteristics That Distinguish the Christian Faith}

At the end of Part 3 Gerasimus adds three more characteristics that distinguish the Christian faith and that affirm that Christianity is the true religion:

A. The Christian religion does not contain any of the five defects that make any other religion and its messenger faulty. Gerasimus had previously listed these five flaws in the Part 2. They are: 1) the wisdom and analogies of this world; 2) the world's passing glory; 3) its transitory richness; 4) its faulty pleasures; 5) fear of its power or its sword. He affirms that none of these five defects are present in the Christian religion nor in the twelve disciples who founded it.

B. The Christian religion is difficult to understand, yet it is proclaimed throughout the world. In Part 3, Gerasimus describes the disciples preaching in this way:

In regards to their preaching, it was hard to believe, or harder to accept than the [preaching] of other religions. The minds of earthly people detest it, and ascribe it to ignorance and foolishness.

23 This idea of eternal life is known in the teaching of the Greek Church Fathers as "the doctrine of spiritual kinship." The Greek Fathers were enthusiastic about the language describing the spirit's "kinship," or, "affinity" with the divine nature; the spirit is a "breath of God" or "spirit emanating from the invisible deity.” Cf. McGukin 2007, 105. 
However, [the disciples] divided the regions of the world, and called its tribes (that are of different denominations, meanings, and morals) to worship a god whose attribute is this: He is One God in three, and three in One. No one is able to describe Him. He is Father, Son and Holy Spirit.

Gerasimus presents this element to show that the Christian message spread throughout the world in spite of its being difficult to understand. The first disciples were not educated, and had no worldly power, or army. Yet the message they preached spread to the four corners of the earth while the messages and the temples of pagans, which were associated with powerful religions, faded. The power of Christianity comes from Jesus Christ, the one who sent the preachers out and promised to always be with them.

C. Christian preaching has a unified message. Gerasimus argues that Aristotle and Plato were not able to agree whether the soul was mortal or immortal, or agree on the nature of the Exalted Creator, while Christians in the four corners of the earth are in agreement with one another (Part 3). The example he gives of this unified Christian doctrine is from the first chapter of the Gospel of John, verses 1 and 14: "In the beginning was the Word, and the Word was with God, and the Word was God." "And the Word became flesh and dwelt among us." ${ }^{4}$

\subsubsection{Signs Which Indicate That a Religion Is Faulty}

Gerasimus divides the signs that indicate a religion is faulty into two categories: Some religions can be seen as false because they are based on the wisdom, standards and criteria of this world; others, for reasons that do not have to do with wisdom and analogical thought. Among signs of falsehood in the second category then he poses two sub-categories: those that are believed voluntarily and those that are are accepted as a matter of coercion. There are in turn three false reasons for voluntary belief: glory, riches and pleasure. In addition to coercion by the sword, however, people can be forcibly brought to belief by the power of God through miracles. Altogether then there are six causes of belief. Five are earthly, or false, and one is heavenly, or true (Part 3).

These signs are adapted from Abū Rāițah in his ninth letter, and from Ibn al-Fațl. ${ }^{25}$ With them Gerasimus is trying to convey to his readers that the Christian religion is difficult to understand, yet is proclaimed throughout the world, aided, not by physical force nor motivated by a desire for power or glory, but by the power of the Holy Spirit.

24 This point will be examined in more detail in Chapter 4 in the response to the first objection.

25 See al-Hūūī 2005a, 315, 318. 


\subsubsection{Gerasimus's Theological Template}

In his argument about religion, Gerasimus rarely strays from the polemical template used by most Arab Christian theologians and seen in the mystical theology of the Greek Church Fathers. Their template can be summarized thus: True religion is the one revealed by God. True religion, in all its many facets, is the content of revelation that is revealed to a disciple and announced to God's people. There are many religions that claim to be the revealed truth. Therefore, the believer is required to discern which religion is revealed by God. The revealed religion is one, because God is One. It would contradict God's character if He revealed multitudes of contradicting religions. There are many false religions, but one true religion. The nature of true religion is always in agreement with the Divine nature, which means that no human endeavors can affect such a religion and it does not include any human efforts or effects.

To discern the divine nature and all that goes with it, two elements are needed: analogical deduction and a miraculous signs. To deduce true religion the mind needs to be healthy, together with a healthy soul/spiritual nature (an unhealthy one being that which is enslaved to the sin inherited from Adam). When the human soul/spiritual nature is sound and healthy, it naturally goes together with the divine nature, because it was created in God's image. Miraculous signs are also important in discerning true revealed religion. This religion's message and disciples must be accompanied by signs and wonders, such that leave no doubt that they are from God. Any religion can have negative as well as positive signs. The negative signs are human aspects that generate false religions. The positive are the miraculous, non-human signs that befit the Divine nature. ${ }^{26}$

Gerasimus introduces two distinct levels of mystical discernment, which he adapts from Gregory of Nyssa. First, through the exercise of spiritual senses, divine illumination occurs. In this process humans recover the healthy mind that was lost to their sinful passions in the fall of Adam. The second level is that of the spirit being united with God. Human beings, after being purified from sin, discover the presence of God in the spirit. As Gregory writes in his homily on the beatitudes,

If a man's heart has been purified from every creature and unruly affections, he will see the Image of the Divine Nature in his own beauty. I think that, in this short saying, the word expresses some such counsel as this: there is in you, human beings, a desire to contemplate the true good; but when you hear that the Divine majesty is exalted above the heaven, that its glory is inexpressible, its beauty ineffable, and its nature inaccessible, do not despair of ever beholding what you desire. It is indeed within your reach; you have within yourself that standard by which you apprehend that Divine. For he who made you did at the same time endow your nature with this wonderful Nature, as if molding the form of a carving into wax. But the evil that has been poured all around that nature bearing the Divine Image has rendered useless to you this wonder-

26 Cf. al-Hुūrī 2005a, 313-333. 
ful thing that lies hidden under vile coverings. If, therefore, you wash off by a good life the filth that has been struck on your heart like plaster, the divine beauty will again shine forth in you. For the Godhead is purity, freedom from passion, and separation from all evil. If therefore these things be in you, God is indeed in you. Hence, if your thought is without any alloy of evil, free from passion, and alien from stain, you are blessed because you are clear of sight. You are able to perceive what is invisible to those who are not purified, because you have been cleansed; that darkness caused by material entanglements has been removed from the eyes of your soul, and you see the blessed vision radiant in the pure heaven of your heart. (Michael 1995, 99)

Gerasimus affirms that this process can begin only through faith in our Lord Jesus and His Gospel, and through our union with the One Who gave His life for us. We enjoy the everlasting bliss when our spirit is united with the One who gave His life for us (Part 3). He frequently refers to the analogy of the sick servant who fails to discern the right, healing medicine to cure his disease until the royal physician meets him and heals him. Gerasimus insists that the Lord Himself is the medicine, and that the way we receive this medicine is through faith and the sacraments of baptism and Eucharist (5:187, 345).

\subsection{Signs of a True Disciple}

Part 2 of Gerasimus's Apology is dedicated to examining the signs of a true disciple. The disciple who claims to proclaim the religion of God and asks people to follow and believe him must demonstrate three signs: first, his preaching must be to all nations; second, a power from God to perform miracles must accompany him; and third, he must be an expert in speaking the language of every nation and tribe. Gerasimus returns to these three signs in the Part 3 where he examines how they were fulfilled in the Christian disciples, thus confirming that the Christian disciple is the true one sent from God.

\subsubsection{General Preaching}

Gerasimus states that analogies used in preaching must refer to a God who is just and who wants all His servants to be saved. He notes that it is God's desire to pour His grace on all people; therefore, the messenger sent by Him must fulfill the goal of preaching to all tribes. Otherwise, the disciple would impede the purpose of God, his calling would be revoked, and he would deserve punishment (Part 2). Gerasimus then presents the parable of a king who calls for a royal banquet, which we will examine in more detail in Chapter 3.

In Part 3 Gerasimus examines how Christ is worshiped and honored in the four corners of the earth, fulfilling the prophecy of David: "Their line has gone out through 
all the earth, and their words to the end of the world" (Psalm 19:4). Then in Part 5, objection 6 , he responds to the challenge to this argument implied by the special status of the Jews in the Old Testament. We will examine that argument more carefully when specifically consider the content of Part 5 here in Chapter 4.

\subsubsection{Performance of Miracles}

The miraculous sign is an imperative one; otherwise, people would have an excuse not to believe, and they could not be punished for not believing (Part 2). In Part 3 Gerasimus returns to this sign to affirm that it was given to Jesus's disciples. He also affirms that the five defects previously mentioned were not present in the disciples. These defects and their causes usually attract many people. However, in the disciples we see the opposite; some did not have wisdom and were illiterate, some were poor and from humble homes, and some were fishermen, practicing a humble profession. Beyond that, their preaching was hard to believe; almost no one accepted their teachings because they were so hard to practice. In regard to the rewards that their religion promised, it was hard for most people to imagine or understand it what they were talking about. Nevertheless, the disciples performed miracles, commanding the lame to stand up in the name of Christ, the blind to open their eyes, the deaf-mute to speak and the dead to rise up. If the power of the one who sent them had not been with them no one would have listened to them (Part 3). Gerasimus then adds that even baptized believers have access to the power to perform these miracles, as their master promised: "And these signs will follow those who believe: In My name they will cast out demons; they will speak with new tongues" (Mark 16:17).

\subsubsection{Speaking the Common Languages}

Gerasimus here refers back to the first sign: Because God wants all nations to be saved, his disciples must be experts in speaking the common languages of the people in order to convey His message (Part 2). In Part 3 he affirms that the disciples were endowed with this sign on the day of Pentecost when the Holy Spirit came upon them and empowered them to speak multiple languages. He also argues that today the name of Jesus is proclaimed and worshiped in all the languages of the world (Part 3).

\subsection{The Existence of God}

In his argument on the existence of God, Gerasimus adopts the format used by the Greek Church Fathers and later on by the Muslim theologians of the al-Mu'tazila 
school. ${ }^{27}$ He makes use of reason and demonstration, allegory and interpretation, in presenting the Christian understanding of a transcendent deity.

\subsubsection{Reason and Demonstration}

Gerasimus maintains that the knowledge of God is acquired both through the senses and by deductive reasoning; we know God by experience rather than by revelation. However, this evidence does not demonstrate the existence of God, but helps to guide the human spirit toward faith. The senses and deductive thinking show that it is reasonable to believe, but they are unable to produce faith itself, which is a gift from God. The human mind and spirit are ill and need "medicine" to recognize the existence of God. It is, therefore, impossible for the human mind to see God unless it is healed and purified from sin, by faith and baptism. ${ }^{28}$

This argument is very similar to Origen's reply to Celsus on the respective role of mind and the senses in our knowledge of God is representative of this view. Celsus had criticized Christians by saying: "How can we know God unless by perception of the senses? For how otherwise than through the senses are we able to gain any knowledge?” To this Origen replies:

Christian philosophers begin with the use of the senses upon sensible objects, in order to go on from them to a knowledge of the nature of things intellectual, yet their knowledge must not stop short with the objects of sense.... Since we hold that the great God is in essence simple, invisible and incorporeal, Himself pure intelligence, or something transcending intelligence and existence, we can never say that God is apprehended by any other means than through intelligence which is formed in His Image. (Henry (trans.) 1953, 36-39)

To Origen, God is the mind and the source from which all intellectual nature or mind takes its beginning. When the mind is purified and separated from material corruption it becomes a means of grasping something of the nature of the Divine. Therefore it is to misunderstand God if we try to apprehend him by means of our bodily senses. ${ }^{29}$

$27 \mathrm{Mu}$ 'tazilah is an Islamic school of theology based on reason and rational thought that flourished in the cities of Basra and Baghdad, both in present-day Iraq, during the 8th-10th centuries. The adherents of the Mu'tazili school are best known for their having asserted that, because of the perfect unity and eternal nature of God, the Qur'an must therefore have been created, as it could not be co-eternal with God. Cf. Casper 1998, 167-186.

28 Cf. Casper 2007, 57-58.

29 Cf. Morris 1964, 52-53. 


\subsubsection{Allegory and Interpretation}

Figurative interpretation flourished in the fifth century B.C. The Greeks devised it to reconcile the older religion of the Homeric world with the new ideas which clashed with it. Greek fathers adapted this method to explain certain passages from the Old Testament that are inconsistent with Christian morality. The goal of the Fathers was to bring the Old Testament in line with their new and more exalted idea of God. ${ }^{30}$

The use of allegory became a matter of dispute in Islam also because it affected the doctrine of the nature of God. While the Qur'an strongly emphasizes the absolute uniqueness of God, it describes Him in anthropomorphic terms, ascribing to Him eyes, hands and a face, and portraying Him as speaking and sitting on a throne. ${ }^{31}$ A verse in the Qur'an that played a part in this dispute was Sūrah 3:7:

He it is who has sent down to thee the Book. In it are verses basic or fundamental [of established meaning muhkamāt]. They are the foundation of the book, others are allegorical mutašābihāt. But those in whose hearts is perversity follow the part thereof that is allegorical seeking discord and searching for its hidden meaning but not one knows its hidden meanings except God. And those who are firmly grounded in knowledge say "we believe in the book; the whole of it is from our Lord” and none will grasp the message except men of understanding.

\subsubsection{Transcendent Deity}

Gerasimus states that God is unknowable, nameless, without part or qualities, and is not spatial. Two quotations from the Church Fathers support this statement. Justin the Martyr says:

But to the Father of all, who is unbegotten, there is no name given. For by whatever name He be called, He has as His elder the person who gave Him the name. But these words, Father and God and Creator and Master, are not names, but appellations derived from His good deeds and functions... the appellation God is not a name but an opinion implanted in the nature of men of a thing that can hardly be explained. ${ }^{32}$

Clement of Alexandria also writes on this subject:

The discourse respecting God is most difficult to handle. For since the first principle of everything is difficult to find out, the absolutely first and oldest principle, which is the cause of all other things, being and having been, is difficult to exhibit. For how can that be expressed which is neither genus, nor difference, nor species, nor individual, nor number: anymore is neither

30 Ibid. 56.

31 Cf. Morris 1964, 57-58.

32 Robert 1988, 20. 
an event, nor that to which an event happens? No one can rightly express Him wholly, for on account of His greatness He is ranked as the All, and is the Father of the universe. Nor are any parts to be predicted of Him. For the one is indivisible; wherefore also it is infinite, nor considered with reference to its being without dimension, and not having limit. And therefore it is without form or name. And if we name it we do properly terming it either the One, or the Good, or Mind, or Absolute Being, or Father, or God, or Creator, or Lord. We speak not as supplying name; but for want, we use good names, in order that the mind may have these as points of support, so as not to err in any other respects. For predicates are expressed either from what belongs to things themselves, or from their mutual relation. But none of these are admissible in reference to God. ${ }^{33}$

From this brief description we can see that the same method of explaining the existence of God was used by Muslims and Christians. They agreed that Divine attributes and names are only human descriptions of God, and these expressions must be interpreted in a way that is fitting with God's majesty. It is on this theological foundation that Gerasimus bases his interpretation on the existence of God. When explaining the mystery of the Trinity, he affirms that it cannot be explained rationally, but the biblical writers resorted to human language to make it accessible to human minds:

Nevertheless, in order not to suppose that He is similar to a mere human word which is ephemeral and has no existence in [and of] itself, (for, to "become" it needs bodily organs such as tongue, wind pipes, and so forth), He was called "Son." Furthermore, in order not to suppose filiation similar to what we have, and what our nature needs, namely, that the father precedes the son in time through a normal human birth process, He was called "the bright glory of the Father.” And in order not to suppose that His attributes are different from the Father and dissimilar to the [Father], (as we see the difference among us humans), He was called, "the form of His person.” And in order not to suppose Him as from a different substance, other than His own substance, He was called "His arm." He is also called, from a different perspective, "His power and His wisdom" (5:65-69).

A distinction needs to be drawn here between theologia - the mystery of God, and oikonomia - the economy of salvation. It is possible to speak about theologia only when that mystery has been recapitulated in oikonomia through Christ's incarnation and deification. The glory of God is revealed in the wonder of creation, but such theological knowledge is still only a pale reflection of what God is. The economy of salvation discloses how God is, without really penetrating the mystery of what God is. ${ }^{34}$ Gerasimus is thus emphatic in stating that even if we are able to explain what divine paternity means, words like "begotten" and "unbegotten," "generated" and "ungenerated" do not express the ultimate substance (ousia) of God, but rather the characteristics of the divine hypostases - how God is toward us (5:61-73).

33 John 1974, 49.

34 Cf. Lacugna 1991, 54-60; Ware 1979, 11-27; Behr 2004, 272-318. 


\subsubsection{Differences Between Arab Christian and Greek Christian Emphases}

The difference between the Greek Fathers and Gerasimus in arguing for the existence of God is that Gerasimus, like other Arab apologists, does not begin with the emphasis on the Triune economy of the One God; instead He begins with the divine unity. Christian Arab apologists developed their argument from the basis of God's absolute oneness, and then showed how the One God was ultimately revealed as a tripartite being through the incarnation. Such a method is necessitated by the assumptions of their Muslim audience. For the Arab Christian apologists, the real questions were why and how God became human while still maintaining continuity with previous monotheistic revelations and without introducing plurality into the divine being.

The question of how the Trinity could be understand through the use of analogy is a major theme in Christian Arabic literature. ${ }^{35}$ According to Khalil Samir, there are two reasons for this. First, Arab Christian authors have been deeply influenced by patristic literature, and this topic is covered extensively in patristic literature. This literature contains a strongly Middle Eastern ethos of the sacredness of God: God lives in inaccessible light. ${ }^{36}$ Second, this same understanding is shared by Muslim theologians. Therefore, Arab Christian apologists felt it was important to develop this theme, particularly when dealing with sensitive topics such as the Holy Trinity which is the most polemical Christian mystery for both Christian and Muslim readers. ${ }^{37}$

\subsubsection{God as Trinity}

Gerasimus examines the concept of the Trinity using the formula of the Cappadocian Fathers: "one substance (ousia) in three persons (hypostaseis)" (ğawhar wāhid wa talātat hawās mušahhhașah). God exists as Father, Son, and Spirit. This Trinitarian ontology is rooted in the self-revelation of God in the divine economy, in the person of Christ, and in the activity of the Spirit (5:74-85).

In a few other areas, Gerasimus also adapts Cappadocian Trinitarian theology: ${ }^{38}$

1) Gerasimus understands the divine paternity as a relational mode of God's being (Father of the Son). He speaks of a differentiation without partition in God. This mode of relation in Trinity was adapted by the Cappadocians from Stoic and Aristotelian

35 Cf. Haddad 1985, 104-114.

36 Cf. 1 Timothy 6:16.

37 See Samir 1994, 72.

38 Cf. Lacugna 1991, 53-59; Ware 1979, 27-43. For an in-depth analysis of the Cappadocian Fathers teachings about the concept of the Holy Trinity see Behr 2004. 
philosophy, and later became an ideal to explain the Trinitarian theology. As Catherine Lacugna $(1991,59)$ explains it:

Father and Son are distinct by relation to each other, but same in ousia. Relation as a category also worked particularly well from Greek Trinitarian theology because relation is farther from substance than any other category, since relation simply refers one thing to another and does not indicate what something is in itself. Thus, to say what God is with respect to relation does not specify what God's ousia is, and thereby does not compromise the principle that God's ousia is unknowable. Nevertheless, by saying what God is according to relation one has said really all that needs to be said, since relation (Father to Son) is the mode of God's being both in the economy and in itself.

2) Hypostasis can be understood in two senses: First, it can mean that which gives support to an object, the elements that form the object. Second, in its transitive sense it means the externally concrete character of a substance in relation to other objects. ${ }^{39}$ When speaking about three hypostases, Gerasimus uses it as was common in the East, to indicate the unity of being.

3) In comparing the consubstantiality of the divine persons to the consubstantiality of human persons, the Cappadocian Fathers ask their hearers to imagine three men, Peter, James and John or Paul, Sylvanus, and Timothy. As human beings, they tell us the three are identical; their humanity is one and the same. But as unique human beings concretely existing, they are distinguished one from another as persons, as distinct hypostases, each with their own names and personal characteristics. ${ }^{40}$ Gerasimus, in responding to the objection that claims that Christians are making God three and worshipping three gods, explains the concept of one God in three substances in a rather Cappadocian fashion:

We, the community of Christians, do not believe this at all, and we do not imagine, as they think we do, that the three Persons (that are the Persons of the Holy Trinity) are separate, as [human] individuals are from each other. For if we were all gathered under one mind, we would share one substance, and one form would prevail over all of us, but we are different in many things (I mean, time, place, determined will, and other characteristics that are parting and dividing us, are different from person to person. They can be found in one individual, but can never be shared with another one). It is to the point that these differences are not only present among us, but every person, from time to time, also experiences transformation, change, and fluctuation, from one state of mind to another. Regarding the Creator of all, although He consists of three persons, the difference is only in the "personified forms and attributes," [that is to say], each person [of the Trinity] has special attributes that distinguish and differentiate Him from the other persons; however, the agreement between [the persons of the Trinity] are many because He is

39 Lacugna 1991, 66.

40 Cf. Hopko 1985, 268. 
one God with one substance, one nature, one honor, and one eternity. ([These characteristics] are not uniform among us humans. Every one of us has a different nature.) The totality of every one of the three is in the totality of the other two, yet He is fully God; and the three are one God, and every one of the three is Himself the other two, except in the personal attributes (mentioned above). Through [these attributes] only, not by any other, [the human] mind distinguishes the one from the other (5:75-82).

\subsubsection{Man as the Image of God}

The idea of the divinization of man that echoes throughout the writings of the Eastern Fathers is clearly used by Gerasimus as well; he follows the traditional Eastern template that divides the history of salvation into three progressive stages: 1) God created man in His likeness and image; 2) man fell; and 3) God restored man by the incarnation of His Son.

The Christological formula of the council of Chalcedon (451 A.D.) that "Christ is one person in two natures," is the theological basis on which Gerasimus builds his apology. He presents the theology of the incarnation as God's identification with humankind. With the incarnation began a process that extends throughout the life of Jesus whereby He embraces all aspects of human experience except sin. Becoming human means the involvement of more than the human body, but the human mind and will as well. Salvation requires that humans somehow be united with the divine, since, as Gregory of Nazianzus wrote, "What has not been assumed cannot be restored; it is what is united with God that is saved." Gerasimus is using the balancing formula of Chalcedon, "one nature in two persons," to affirm both the distinctness and unity of the divine nature with the human one. ${ }^{41}$

Gerasimus elaborates extensively on the theological term, the "image of God." A text of central importance to this term is Genesis 1:27, which speaks of humanity being made in God's image and likeness. God created everything through His Word and through the Word He gave humanity a share in His Image, that is, His Son Jesus Christ. Thus, the relationship between God and creation, and in particular, between God and man, is through the Word.

This approach is found in the Patristic period which interprets "the image of God" in terms of human reason; a few aspects of human reasoning are evident in Gerasimus's Apology and merit our attention. The image is understood to be the human rational faculty, which mirrors the wisdom of God..$^{42}$ The image is also associated with the totality of man's nature, considered as trinity of spirit, soul and body. At other times Greek Fathers connected the image more specifically with the highest aspect of man,

41 Cf. Lowe 1994, 226-229.

42 Cf. Bof 1994, 1830; and McGrath 2001, 440-448. 
with his spirit or spiritual intellect, through which he attains knowledge of God and union with Him. Basically, the image of God denotes everything that distinguishes man from animals and that makes him in the full sense a person, a moral agent capable of right and wrong, a spiritual subject endowed with inward freedom.

Another aspect of the image that is particularly important in the Apology is the gift of free choice. As God is free, so likewise man is free, and being free, each human being realizes the divine image within himself in his own distinctive fashion. ${ }^{43}$

Many Eastern Fathers draw a distinction between the "image of God" and "the likeness of God.” The image, for those who distinguish between the two terms, denotes man's potentiality for life in God. The likeness is his realization of that potentiality. The image is that which he possesses from the beginning, and which enables him to set out in the first place upon the spiritual way. The likeness is that which he hopes to attain at the end of his journey. ${ }^{44}$

The image and likeness signify orientation, relationship. Being created in the image of God means man is created for communion and union with God, and if man rejects this communion, he relinquishes the position of man in the image of God. The doctrine of the image means, therefore, that man has God as the innermost center of his being. The divine is the determining element in our humanity; by losing our sense of the divine, we also lose our sense of humanity.

In Part 3, when Gerasimus compares Christian law to the laws of other religions, he describes their laws as those which transform the natural image of man made in the likeness of God to the image of untamed beasts. The central point of his argument is that human nature has its God-given ability to relate to God, and although human reason has been corrupted by the Fall, it may be renewed by grace. Also in Part 3, when he speaks about the two kinds of life and death, he defines spiritual life as an instinctive spiritual desire that God formed in man, through which man desires the union of the spirit with Him in divine bliss. However, Gerasimus affirms that the movement toward God must be healthy, for if it is ill (filled with wrong motives), it will desire what corrupts and makes the spirit miserable. Then he concludes that as the body needs nutrition from food and drink to survive, God Himself became the nutrition that the human spirit needs to survive. He gave Himself that we may be united with Him and be delighted in His divine nature.

The doctrine of creation in the image of God is also seen as being directly related to the doctrine of redemption. Redemption involved bringing the image of God to its fulfillment in a perfect relationship with God culminating in immortality. In Part 3, when he speaks about the Christian eternal reward, Gerasimus articulates it in this way: "This is the union with the Sublime God and the delight in His divinity in the

43 Cf. Migliore 2004, 141.

44 Cf. Ware 1979, 51. 
eternal bliss (that has no ending), that we become gods in His Likeness, and we attain, by grace, what He has by nature."

It is worth noting that Gerasimus follows the pattern of the Eastern Church Fathers that emphasizes the positive side of redemption; God saved us out of His goodness and mercy. There is no mention of the wrath of God. ${ }^{45}$ Redemption is seen as reconciliation between Jews and Gentiles, heaven and earth, and human nature and God its Creator (5:426). By redemption, man is returned to the position he held before the Fall, ruler over creation, thus defeating Satan and gaining victory over hell (5:430-432). Redemption destroys the barrier that stands between heaven and earth, and eliminates the flashing sword that guards the way to the Tree of Life (5:431). ${ }^{46}$

\subsection{Conclusion}

Throughout the Apology Gerasimus presents humanity as universally affected by sin as a consequence of the Fall. The human mind has become darkened and weakened by sin, which makes it impossible for the sinner to think clearly in order to understand higher spiritual truths. An analogy that Gerasimus uses effectively is sin as disease. Sin weakens humanity, causing spiritual disorder. Being a sinner is as though a person were physically ill and unable to diagnose his own illness. Salvation is understood in sanative, or medical terms. We are healed by the grace of God so that our minds may recognize God and our wills may respond to the divine offer of grace. For it is through the grace of God alone that the illness is diagnosed and cured.

A second analogy that Gerasimus employs treats sin as a power which holds us captive and from whose grip we are unable to break free by ourselves. Human free will is captivated by the power of sin, and may only be liberated by grace. Christ is thus our liberator, the source of grace which breaks the power of sin.

45 Cf. Coptology 2006.

46 Cf. Genesis 3:24. 